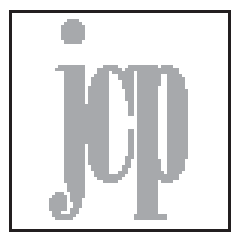

\title{
Narrative Violence in Toni Morrison's Jazz
}

\author{
Jaleel Akhtar \\ Assistant Professor, COMSATS, Lahore \\ dr.jaleel@hotmail.com
}

Tahoor Ali

Student of MS Linguistics and Literature, COMSATS, Lahore

\begin{abstract}
This essay looks at forms of narrative violence and their ramifications in Toni Morrison's Jazz. It outlines violence by highlighting its importance as one of the common ingredients in the art of storytelling and history of American literature, focusing on Morrison's Jazz and how theorists like Rene Girard respond to the mechanism of violence. The essay investigates the role of the elusive third-person omniscient narrator who is the source of narrative violence in Jazz. Morrison's construction of the narrator in Jazz subverts Roland Barthes' concept of a gradual decline in the narrative authority of the author or the narrator by demonstrating how the narrator can be a misleading or unreliable source of information. For example, the narrator predicts many things in the novel which fail to occur. This essay contends that the kind of epistemological authority and power which the narrator exercises over the lives of characters as well as the expectations of the reader are invasive. If a narrator, as in Jazz, calls upon the readers to imagine a story and its projected ending from the authoritarian perspective of the narrator without allowing the reader to engage his own imagination or critical faculties, it will render the experience of reading any novel or text a by-product of epistemological or narrative violence. The essay concludes by offering an alternative version of epistemology in which the characters evolve along with the reader and the narrator by way of achieving a greater epistemological agency and awareness.
\end{abstract}

Keywords: Narration, Violence, Touch, Epiphany, Subjectivity 
I break lives to prove I can mend them back again. And although the pain is theirs, I share it, don't I? (Morrison, Jazz 219)

A story is not merely an account or recounting of events, it involves an organizing principle which makes these events intelligible, conveying both information and understanding of narrative discourses to the reader. According to Andrew Bennett and Nicholas Royale, stories are central to our understanding of life, to our understanding of the mysteries of life or love as the narrator in Jazz invites the reader to think about (5). Our lives are shaped by them. Stories are about what happens in our daily lives and dreams. They are about violence, war and peace. They are about how we fall in love. We may tell them but they also tell us, as they are everywhere (52), we are also in them. According to Bennett and Royale, narrative is one of those aspects that shapes the human existence by endowing upon it "a sense of who we are" (52). Violence is a common ingredient of storytelling, as pointed out by the literary duo Bennett and Royale. It is not merely a universal phenomenon which the famous cultural theorist Rene Girard finds at the heart of the sacred, it is also a vehicle of narrative violence the way Morrison expostulates it, with the help of the omniscient narrator in Jazz. In this paper, we investigate narrative violence in Toni Morrison's novel Jazz. Narrative violence constitutes a substantial part of every novel in American literature from the nineteenth and twentieth centuries. Before we elaborate our concept of narrative violence, we would like to dwell upon our common understanding of narrative theory. Narrative is the genre of storytelling. It is also known as a genre of explanation. Narrative is present in almost all human discourse. Fredric Jameson in The Political Unconscious: Narrative as a Socially Symbolic Act says that narrative is "the central function or instance of [the] human mind" (13). Barthes, in his landmark essay "An Introduction to the Structural Analysis of Narrative" maintains that there are innumerable narratives in the world, important and compulsory for all genres. Narraitive is carried by language (spoken and written), images and gestures. It is present in myth, legend, novel, history drama. It is present in every age, every class, and every history and in every piece of good and bad literature (1). Gerard Genette, in his Figures of Literary Discourse, suggests that "one will define narrative without difficulty as the representation of an event or of a sequence of events" (127). Genette's concept of narrative highlights the role of the narrator in presenting these events in a sequential order. Narrative contains the multidimensional events of life, events of love, hatred, violence, slavery, dreams and ideas, thus the role of the narrator is central to explicating the specific order of events. The narrator is a person or a character, who may be 
the mouthpiece of his/her author in terms of recounting the events in a story. The narrator is considered as a link between the author and the reader. The term 'narrative' certainly is not used as commonly as 'story'. Most people know that it refers, in some way, to stories that are endemic to our lives. Barthes, in his $S / Z$, has influenced forms of study whereby meanings are produced by texts through semiotics. He argues that there is a possibility of one or more out of five codes (Hermeneutic, Proairetic, Semantic, Symbolic, and Referential) that describe the meaning of a text (19).

These are some of the general theories about narrative art in the western academy. But the aim of my study is to look at the role of the narrator as a source of violence in Morrison's Jazz, which one can link to the history of violence in American literature. For example, in the works of Charles Brockden Brown, the secret motivation behind Brown's characters is violence. Violent acts of murder and rape are the essential events in his novels. Another example is James Fenimore Cooper, who is a prolific writer of American literary history. His novels The Last of the Mohicans, The Pioneers and The Prairie revolve around innumerable narratives of violence, war, death and the killing of Indians. The tales of Edgar Allan Poe are also full of narrative violence. Events of violence are woven into almost all of his famous short stories. Human violence operates as the subtext in American literature such as murder, stoning, lynching, torture, crime and abusive behaviour. As David Michael Buss in his The Murderer Next Door: Why Mind Is Designed to Kill, says:

Murder gives us an X-ray of inner core of human nature. It lays bare the things that matter most to humans everywhere - the necessities of survival, the attainment of status, the defense of honor, the acquisition of desirable partners, the loyalty of our lovers, the bonding of our allies, the vanquishing of our enemies, the protection of our children, and the successor of carriers of our genetic cargo. These are the things that we humans and our astonishingly victorious ancestors have always been willing to kill and die for.(244)

Literature reflects upon these kinds of overt and covert violence. Sigmund Freud reads this principle of violence in literature as a death principle and Maurice Blanchot reads it as a death sentence. These theorists, including Girard, read violence as being at the core of all conflicts in the society and social relationships. If one wants to analyse the prevalence of violence, first of all one needs to analyse the relationships of people within their society as well as the analysis of cultural values and individual differences. One can read narrative violence as constitutive 
of the events which contain actions involving physical or psychological force with the intention to hurt, torture or kill characters in a story. Michael Kowaleski in his Deadly Musings:Violence and Verbal Form in American Fiction says that "violence is a catch-all term, a kind of verbal wooden nickel, used with such frequent ease that its actual indeterminate status appears almost self-evidently clear” (10).

In Jazz, violence is depicted as an aggressive state of mind which is both destructive and antisocial, as in case of Joe's act of violence which cuts him off from society as well as from his wife. The narrator in Jazz has epistemological authority and power over the events in the novel and seems to control the characters as well as the expectations of the reader. If a narrator, as in Jazz, calls upon the readers to imagine a story and its projected ending from the authoritarian perspective of the narrator without allowing the reader to engage his own imagination or critical faculties, it will be a deaf blind experience for the reader (Hall 2). Such literary experience which stupefies the reader's imagination is a by-product of epistemological or narrative violence. The role of the narrator creates an atmosphere of ambivalent violence in Jazz. This is because his or her narration operates within the dynamics of power relations. For example, starting with Morrison's earliest novels, like The Bluest Eye up to her most recent novel God Help the Child, the reader can read a pattern of binary oppositions or polar dichotomies unfolding themselves in terms of the thematic content, like good and evil, beauty and ugliness. In her storytelling, the narrator seems to operate from a site of power through which s/he subjects his/her characters to positions of subordination, subjugation and dominance. The position of the narrator defines hierarchies of subject/object position, i.e., between the coloniser and colonised, the definer and the defined, the confessor and the confessant, the scapegoat and the scapegoated, the victim and the victimiser, the dominant and the dominated, the murderer and the murdered. These hierarchised relations, between subject and object positions are based upon unequal power relations in which the object finds himself/herself at the mercy of these hierarchised relations and becomes the object of epistemological or narrative violence, which we see as a condition of narrative violence.

In our present study of Morrison's novel Jazz, we intend to look at the role of the narrator and how s/he occupies this site of narrative violence. Expanding upon Rene Girard's concept of violence being at the heart of the sacred, we postulate that violence is at the heart of Morrison's art of storytelling, as far as the role of the narrator is concerned in her novel. My main contention is that the narrator 
subjects the characters to narrative violence. For example, in the beginning of the novel, after the narrator has encapsulated the scene of murder, in which Joe kills his paramour Dorcas and his wife Violet and tries to disfigure the dead body of Dorcas, the narrator predicts another scene of murder, "Violet invited her in to examine the record and that's how that scandalizing threesome on Lenox Avenue began. What turned out different was who shot whom" (6). The narrator introduces the reader to the shooting of Dorcas, ex-girlfriend of Joe Trace and Violet, who tries to cut the face of the dead body. It deals with a different kind of violence, which is paradoxically an act of possessive love. In this novel, there are two narrative levels of violence: private and social. Private violence revolves around the subjective lives of Violet and Joe Trace. Social violence operates at historical level, which has impacted on the lives of the characters since their childhood in the form of suicides, beatings, racial violence and inherited violence of slavery. These instances of historical violence in the narrative can be traced back to Joe's rejection by his mother, Wild. He is motherless. Her presence is allusively out of his reach. His mother's absence or lack of love leaves an emotional vacuum in his life. The novel describes it in terms of an "inside nothing" (37). Both Violet and Dorcas have a similar emotional vacuum, which they try to fill with each other. Terry Otten reads this instance of narrative violence in which Joe tries to appropriate the subjectivity of Dorcas as "the culmination of Joe's struggle to touch his mother's hand" (662). Joe did not want to shoot Dorcas. He meant no harm to his paramour. He just wanted to touch her. The novel presents Joe's act of touching as violent gesture. Morrison in an interview with Jane Bakerman “The Seams Can't Show: An Interview with Toni Morrison" points out that "we have a lot of rage, a lot of violence; it comes too easily to us. The amazing thing to me is that there is so much love also [...] violence is a distortion of what perhaps we want to do". What Joe wants is to touch Dorcas tenderly. But he forgets the advice he gets from Henry the hunter, "never kill the tender and nothing female if you can help it. Didn't think I had to teach you about people. Now, learn this: she ain't prey. You got to know the difference [...] He isn't thinking of harming her, or, as Hunter had cautioned, killing something tender. She is female. And she is not prey. So, he never thinks of that" $(175,181)$. He forgets the advice and his touch becomes appropriative. It destroys Dorcas' subjectivity. It does not respect her alterity. After the narrator discribes these scenes of violence, s/he proclaims that $\mathrm{s} /$ he can break or mend the lives of his characters. It seems as if, like the Greek Furies, like a merciless handler of fate, s/he can manipulate the lives of his/her character and the course of actions at will. As the narrator says "I 
break lives to prove I can mend them back again. And although the pain is theirs, I share it, don't I?" (219). It reveals the narratorial power and authority. We can connect this form of expression with the way the narrator projects violence at the beginning of the novel and seems to take sadistic gratification, by the end of the novel, in which $\mathrm{s} /$ he asserts that $\mathrm{s} /$ he has the power to inflict pain upon characters. In other words, s/he takes full responsibility for bringing about tragic devastation or violence. Since the narrator prophesies another murder scene, the reader finds himself/herself full of anticipation. The narrator reveals his / her calculated, predetermined and fatalised views about the fate of characters, "I was sure one would kill the other. I waited for it so I could describe it. I was so sure it would happen. That the past was an abused record with no choice but to repeat itself at the crack and no power on earth could lift the arm that held the needle" (220). As in the past, lovers are dismissed, rejected and murdered, mistrust and death rules over the story. The narrator thinks that once again $\mathrm{s} /$ he will be able to cause such violence in the lives of his/her characters without realising that the characters are evolving and reclaiming their lives. Just like the account of Golden Gray whom the narrator ruefully admits to have "imagined so poorly," the narrator forgets that the characters are improvising their lives all along: "It never occurred to me they were thinking other thoughts, feeling other feelings, putting their lives together in ways I never dreamed of" $(116,229)$. $\mathrm{S} /$ he finally admits her fallibility, acknowledges her/his flaws and lets go of his/ her despotic narrative hold (220). S/ he is playing with readers' expectation which is a psychological form of violence. The reader finds himself at the mercy of the narrator. Morrison undermines the narrator as a reliable source of information because $\mathrm{s}$ /he is a source of epistemological violence. In fact, as Goulimari observes, "Morrison rejects the narrator's position of authority" in relation to her work, her predictions about the characters and their lives (218). Morrison wants her readers to make their own interpretations of her work. Readers must construct the narrator's identity and question the narrator's reliability in telling the stories of Joe Trace, Violet Trace, Golden Gray and Dorcas Manfred. The novel invites the reader to join in a collaborative process of tracing and interpreting the events. The narrator uses techniques of flash-back and flash-forward to draw on the accounts of violence from the past and forecasts the violence in the future. But at the end, the narrator finds that s/he could not predict correctly. According to Pelagia Goulimari, this is how Morrison educates the narrator who finally "gives up earlier claims of omniscience and omnipotence suitable to the authorial persona of author-God" and his/her know-it-all perspective (97). Morrison 
wants to engage the reader in the process of creation and re-creation of their own selves to understand changing and evolving angles of violence. There is no standard scale of measuring ourselves, identities of other people and violence caused by the narrator.

Jaleel Akhtar in his Dismemberment in the Fiction of Toni Morrison says that Morrison "develops her narratives through an interactive dialogue between various voices and perspectives. Similarly, she encourages the reader to study her fiction via the interrelationship between or dialogization of different perspectives" (1). To extend this, one can say that the characters in her novels, especially Jazz, reverse those dichotomies, we mentioned earlier. They take the reigns into their own hands and start making sense of the moment. Even the narrator realises this interesting reversal of roles, "when I invented stories about them [...] I was completely in their hands" (220). In an interview with Angels Carabi, Morrison says she wanted to "get rid of that notion of the omniscient narrative voice" which is a traditional figure of authority who narrates the story from the vantage point of "I know everything". When a narrator says s/he knows everything, $\mathrm{s}$ / he intrudes upon the reader's sensibility, expectation and understanding. This is epistemological violence, as the narrator confuses the readers' sensibilities, critical faculties and capacities to bring in his/her own understanding of the text. As readers, we depend too much upon the opinion, authority and guidance of the narrator, so we become victims of his/her epistemological vantage point. $\mathrm{S} /$ he subjects the reader to narrative epistemic violence by proclaiming to know everything and, later on, by being apologetic for his/her wrong assumptions. $\mathrm{S} /$ he apologises for his/her errors of judgement at the end when s/he says that "[she] can't really be expected to defend [herself]" (8). Here the narrator is not being self-defensive indulging in a moment of self-excuse, but in fact, $\mathrm{s} /$ he seems to give a cue to the reader not to depend too much upon her/his authority. Time and again the narrator plays with understanding of the reader, which is considered to be epistemological and psychological narrative violence.

Jennifer Lee Jordan Heinert in Narrative Conventions and Race in the Novels of Toni Morrison says that "the narrator is incorrect about the plot; it never fulfills what the narrator forecasts and readers are tricked by what the narrator claims to know from the very first lines of the story" (61). According to Heinert, the narrator is misleading the reader. $\mathrm{S} /$ he misuses his/her power and authority over the story all along. S/he misleads them by being all-knowing and deeply self-opinionated about himself/herself and the story, so this is another way in which the narrator 
imposes violence on the reader as well. The narrator has pretensions which are misinformed and become a source of misguidance or confusion for the reader. This kind of narrative violence destabilises readers' reading and understanding of the text. As a source of authority, the narrator disrupts, intrudes and violates the reader's expectations, sensibilities, and understanding of the text. The narrator does violence to their reader's imagination because Morrison's aim is to actively engage the reader in a process of understanding and reading so $\mathrm{s} / \mathrm{he}$ can deconstruct the meaning of the text by himself/herself. Morrison does take her stance against the violent authority of the narrator. She says that, she wants to depose the narrator from his/her position of ultimate authority. Jazz has a thrust of violence, as predicted by the narrator at the beginning of the novel. But the projected scene of murder never takes place. In fact, the reader, finds all the characters on the mend, they are mending their own personal selves and their relationships with each other via a process of reclamation. By the end of the novel, Morrison has made her statement against the role of the third person all-knowing omniscient narrator; she undermines the all-knowing authority of the narrator at the end, by demonstrating how characters are evolving all along, not only in terms of their interpersonal relations but also in term of their relations vis-a-vis the reader. They are no longer at the mercy of this violent narrator because they have evolved:

I am uneasy now. Feeling a bit false. What, I wonder, what would I be without a few brilliant spots of blood to ponder? Without aching words that set, then miss, the mark? [...] and they danced and walked all over me. Busy, they were, busy being original, complicated, changeable - human, I guess you'd say, while I was the predictable one, confused in my solitude into arrogance, thinking my space, my view was the only one that was or that mattered. I got so aroused while meddling, while finger-shaping, I overreached and missed the obvious. (219-220)

The narrator could not foresee the characters as evolving and taking control over their lives. By the end of the novel, they have reconciled with each other and achieved autonomy. Having reformed their lives, they teach the reader that it is possible to overcome the violence of their past lives. After this evolution of the characters, the narrator cannot claim any authority over their lives. This is the moment of epiphany not only in the lives of the characters and the narrator, but also for the readers. I would like to sum up my argument with some help from Morrison. In her interview "Google Play presents: Toni Morrison Digital Book Signing" she comments upon the moments of 'epiphany' in the lives of her characters when they realise their errors, by the end of the novels. This, broadly 
speaking, defines the trajectory of her narrative art. She comments that her characters realise their 'confusion', and move on from ignorance to knowledge, from violence to peace and more enlightened understanding of themselves. This seems to be the ultimate moment of resolution in Jazz, which the narrator fails to take into account. Morrison undermines the narrator's position of authority in relation to his/her storytelling and the constant evolution of the characters. I argue that to blindly follow the narrator is a way to limit the lives of the characters and our understanding of their complicated lives, motivations and evolution, which is the genesis of epistemic violence in the novel. The least desirable thing that the reader wants is a narrator who predicts/shoots first and then apologises later.

\section{Works Cited}

Akhtar, Jaleel. Dismemberment in the Fiction of Toni Morrison. Newcastle upon Tyne: Cambridge Scholars Press, 2014. Print.

Bakerman, Jane. “The Seams Can't Show: An Interview with Toni Morrison.” Black American Literature Forum. School of Education, Indiana State University, 1978. Print.

Barthes, Roland. S/Z. Trans. Richard Miller. New York: Hill and Wang, 1974. Print. Barthes, Roland and Lionel Duisit. "An Introduction to the Structural Analysis of Narrative.” New Literary History 6.2 (1975): 237-272. Print.

Bennett, Andrew, and Nicholas Royle. An Introduction to Literature, Criticism and Theory. 4th ed. New York: Routledge, 2014. Print.

Buss, David Michael. The Murderer Next Door:Why the Mind Is Designed to Kill. Penguin, 2006. Print.

Carabi, Angels. "Interview with Toni Morrison.” Belles Lettres 10.2 (1995): 40-43. Print.

Cooper, James Fenimore. The Pioneers. New York: Oxford UP, 1999. Print.

---. The Last of the Mohicans. New York: Oxford UP, 1998. Print.

---.The Prairie. New York: Oxford UP, 1987. Print.

Cutter, Martha J. "The Story Must Go On and On:The Fantastic, Narration, and Intertextuality in Toni Morrison's Beloved and Jazz." African American Review 34.1 (2000): 61-75. Print.

Genette, Gerard. Figures of Literary Discourse. Trans. Marie-Rose Logan. New York: Columbia UP, 1982. Print. 
Girard, Rene.The Scapegoat.Trans. Yvonne Freccero Baltimore.The Johns Hopkins UP, 1989. Print.

---. Violence and the Sacred. Trans. Patrick Gregory. Baltimore: The Johns Hopkins UP, 1977. Print.

Google Play. "Google Play presents: Toni Morrison Digital Book Signing.” Online Video Clip. YouTube. YouTube, 27 Feb. 2013: n. pag. Web. 24 Apr. 2017.

Hall, Alice. Literature and Disability. London: Routledge, 2015. Print.

Heinert, Jennifer Lee Jordan. Narrative Conventions and Race in the Novels of Toni Morrison. New York: Routledge, 2009. Print.

Jameson, Fredric. The Political Unconscious: Narrative as a Socially Symbolic Act. London: Routledge, 2013. Print.

Kowalewski, Michael. Deadly Musings: Violence and Verbal Form in American Fiction. New Jersey: Princeton UP, 1993. Print.

Mbalia, Doreatha Drummond. "Women Who Run With Wild: The Need for Sisterhoods in Jazz.” Modern Fiction Studies 39.3 (1993): 623-646. Print.

Morgenstern, Naomi. "Literature Reads Theory: Remarks on Teaching with Morrison." University of Toronto Quarterly 74.3 (2005): 816-28. Print. Morrison, Toni. God Help the Child. London: Random House, 2016. Print. ---.Jazz. London: Picador, 1993. Print.

---. Sula. London: Random House, 1998. Print.

---. The Bluest Eye. London: Random House, 1999. Print. 